\title{
EFEK IMUNOSTIMULAN INFUS BUAH MAHKOTA DEWA (PHALERIA MACROCARPA (SCHEFF.) BOERL.) ASAL KAB. SIDRAB SULAWESI SELATAN TERHADAP SEKRESI ANTIBODI TIKUS PUTIH (RATTUS NORVEGICUS) JANTAN DENGAN TEKNIK HEMAGLUTINASI
}

\author{
Andi Emelda*, Safriani Rahman*, Hardianti \\ *Fakultas Farmasi Universitas Muslim Indonesia
}

\begin{abstract}
Phaleria macrocarpa has chemical constituents that are flavonoids. Flavonoids may act as antioxidants and modulate the immune system. This study aimed to determine the effect of immunostimulatory infusion Phaleria macrocarpa using hemagglutination method. The animals were white rats (Rattus norvegicus) male. The animals were divided into 5 groups. Group I (control), group II (SDMD 5\%), group III, IV and V are the groups given Phaleria macrocarpa infusion at the dose of $7.5 \%, 15 \%$ and $30 \%$ respectively for 7 days. The animals were induced SDMD 5\% intraperitoneally. Observations were made with a view the agglutination titer blood serum of the mice with SDMD. The results showed that infusion of Phaleria macrocarpaprovide the highest concentration at the $7.5 \%$ for titer antibody.
\end{abstract}

Keywords: Phaleria macrocarpa, Imunostimulant, Immunoglobulin, Hemagglutination

\begin{abstract}
ABSTRAK
Buah mahkota dewa mempunyai kandungan kimia yaitu flavanoid. Flavanoid dapat berfungsi sebaigai antioksidan dan memodulasi sistim imun. Penelitian ini bertujuan untuk menentukan efek imunostimulan infus buah mahkota dewa menggunakanmetode hemaglutinasi. Hewan uji yang digunakan pada penelitian ini adalah tikus putih (Rattus norvegicus) jantan. Hewan uji dibagi menjadi 5 kelompok. Kelompok kontrol, kelompok II (SDMD 5\%), kelompok III, IV dan V adalah kelompok yang diberi infus buah mahkota dewa dengan dosis berturut-turut 7,5\%, 15\% dan 30\% selama 7 hari.Hewan uji diinduksi dengan SDMD 5\% secara intraperitonial. Pengamatan dilakukan dengan melihat titer aglutinasi serum darah tikus dengan SDMD. Hasil pengamatan menunjukkan bahwa infus buah mahkota memberikan titer antibodi tertinggi pada konsentrasi 7,5\%.
\end{abstract}

Kata Kunci: Imunostimulan, Mahkota Dewa, Imunoglobulin, Hemaglutinasi

\section{PENDAHULUAN}

Mekanisme yang digunakan tubuh sebagai perlindungan penyakit infeks adalah Sistim imun.Imunoglobulin adalah sistem imun spesifik dan merupakan substansi pertama yang diidentifikasi sebagai molekul dalam serum yang mampu menetralkan sejumlah mikroorganisme penyebab infeksi. Imunoglobulin $\mathrm{G}$ merupakan molekul efektor yang paling banyak dalam sistem imun humoral. IgG umum melapisi mikroorganisme sehingga lebih memudahkan untuk difagositosis. IgG juga mampu menetralisir toksin dan virus. Untuk meningkatkan sistem imun dapat menggunakan senyawa imunostimulan (Baratawidjaja, 2009; Gunawan, 2006; Srihidayati, dkk, 2012).

Senyawa flavonoid diduga dapat meningkatkan sistim imun. Salah satu tanaman yang mengandung senyawa 
flavanoid adalah mahkota dewa. Taaman mahkota dewa juga mengandung senyawa alkaloid, tanin, saponin dan polifenol (Aurelia, 2006; Mulyaningsih, 2007; Nugroho, 2012; Wibowo, 2013).

Penelitian buah mahkota dewa dengan dengan menggunakan air rebusan buah tersebut diuji terhadap aktivitas fagositosis makrofag dan produksi reactive oxygen intermediate (ROI) makrofag pada mencit yang diinfeksi dengan Salmonella typhimurium memberikan hasil peningkatan nilai indeks fagositosis makrofag dan produksi ROI makrofag pada mencit (Aurelia,2006 \& Maratani, 2006).

Penelitian ini bertujuan untuk memberikan konsentrasi buah mahkota dewa yang dapat mensekresi antibodi dengan parameter titer antibodi

\section{METODOLOGI PENELITIAN}

\section{Populasi dan Sampel}

Sampel yang digunakan adalah buah mahkota dewa (Phaleria macrocarpa (Scheff.) Boerl.) yang diperoleh dari Desa Dongi, Kecamatan Pituriawa, Kabupaten Sidrap, Propinsi Sulawesi Selatan

\section{Pengambilan Sampel Buah Mahkota Dewa}

Sampel yang digunakan diperoleh dari Desa Dongi, Kecamatan Pituriawa, Kabupaten Sidrap, Propinsi Sulawesi Selatan.

\section{Pembuatan Infus Buah Mahkota Dewa}

Infus yang dibuat adalah infus buah mahkota dewa konsentrasi 7,5\%, $15 \%$, dan $30 \%$. Untuk membuat infus dengan konsentrasi 7,5\% diperlukan 7,5 gram buah mahkota dewa kering. Buah mahkota dewa dimasukkan ke dalam panci infus dan ditambah air suling sebanyak $15 \mathrm{ml}$ (2 kali berat sampel yang digunakan). Panci infus dipanaskan diatas kompor selama 15 menit sambil sekalikali diaduk dihitung mulai suhu dalam panci mencapai $90{ }^{\circ} \mathrm{C}$. Kemudian ditambahkan air hingga $100 \mathrm{ml}$. Panci infus dipanaskan di alat pemanas selama 15 menit dihitung mulai suhu dalam panci infus mencapai $90{ }^{\circ} \mathrm{C}$ sambil sekali-kali diaduk. Hasil infus kemudian disaring dengan kain penyari hingga diperoleh cairan infus. Ditambahkan air suling hangat melalui ampasnya sampai mencapai volume $100 \mathrm{~mL}$. Dengan cara yang sama dapat dibuat infus dengan konsentrasi $15 \%$ dan $30 \%$.

\section{Penyiapan Suspensi Sel Darah Merah Domba (SDMD) 5\%}

Darah domba segar yang telah diberi antikoagulan disentrifugasi dengan kecepatan 3000 rpm selama 5 menit untuk memisahkan plasma dari sel darah merah. Lapisan atas yang berupa plasma dibuang dan pada lapisan bawah yang berupa endapan sel darah merah, ditambahkan larutan PBS pH 7,2 sebanyak tiga kali volume SDMD yang tersisa. Tabung kemudian dibolak-balik dengan perlahan-lahan sampai SDMD tercampur secara homogen, kemudian disentrifugasi lagi. Prosedur ini diulang sampai lapisan atas benar-benar jernih dan tidak berwarna. Lapisan atas yang jernih dibuang dan lapisan bawah adalah SDMD murni. SDMD dipipet, dan ditambahkan PBS dengan volume sama sehingga didapat suspensi SDMD 50\%. Untuk mendapatkan suspensi SDMD 5\%, maka diambil $1 \mathrm{ml}$ suspensi SDMD 50\% dan ditambahkan PBS ad 10ml (pH 7,2).

\section{Penyiapan Hewan Uji}

Sebanyak lima belas ekor tikus putih jantan diadaptasi selama 2 minggu, kemudian dibagi dalam 5 kelompok, yang masing masing-masing terdiri dari 3 ekor tikus. Kelompok I adalah kontrol normal dengan pemberian air suling, kelompok II adalah kelompok yang hanya diinduksi dengan SDMD, kelompok III adalah infus buah mahkota dewa konsentrasi 7,5\%, kelompok IV adalah infus buah mahkota dewa 
Efek Imunostimulan Infus Buah Mahkota Dewa (Phaleria macrocarpa (Scheff.) Boerl.) Asal Kab. Sidrab Sulawesi Selatan terhadap Sekresi Antibodi Tikus Putih (Rattus Norvegicus) Jantan dengan Teknik Hemaglutinasi

konsentrasi 15\%, dan kelompok V adalah infus buah mahkota dewa konsentrasi $30 \%$.

\section{Perlakuan Terhadap Hewan Uji}

Pada hari pertama kelompok II, III, IV, dan V diimunisasi dengan SDMD $5 \%$ dengan volume $0,1 \mathrm{ml}$ secara intraperitonial. Untuk kelompok I (kontrol normal) dibiarkan tanpa perlakuan. Beberapa jam setelah diinduksi, hewan diberi air suling untuk kelompok II (kontrol SDMD), untuk kelompok III hewan diberi infus buah mahkota dewa dengan konsentrasi 7,5\%, kelompok IV diberi infus buah mahkota dewa dengan konsentrasi $15 \%$ dan kelompok $\mathrm{V}$ diberi infus buah mahkota dewa dengan konsentrasi 30\%. Volume pemberian disesuaikan dengan berat badan tikus. Pemberian secara oral setiap hari selama 7 hari. Pada hari ketujuh darah diambil secara intravena melalui ekor pada masing-masing kelompok.

\section{Teknik Pengambilan Sampel Darah}

Pengambilan sampel darah tikus putih (Rattus norvegicus) Jantan sebanyak $0,5 \mathrm{ml}$ melalui ekor.

\section{Pengujian Sekresi antibodi}

Sampel darah dibiarkan membeku atau menggumpal pada suhu kamar selama $1-2$ jam, selanjutnya disentrifus dengan kecepatan $3000 \mathrm{rpm}$ selama 10 menit dan diambil serumnya (supernatan). Sebanyak $50 \mu \mathrm{L}$ serum darah tikus diencerkan ke dalam $50 \mu \mathrm{L}$ PBS pada sumur mikrotitrasi (wheel plate). Serum selanjutnya diencerkan secara bertingkat yaitu dari pengenceran yang pertama dipipet $50 \mu \mathrm{L}$ dan diencerkan dengan PBS $50 \mu \mathrm{L}$ menjadi pengenceran $2 \times(1 / 2)$, dari pengenceran yang kedua dipipet $50 \mu \mathrm{l}$ dan diencerkan dengan PBS $50 \mu \mathrm{L}$ menjadi pengenceran $4 \times(1 / 4)$. Pengenceran dilanjutkan dengan cara yang sama menjadi $8 \times(1 / 8), 16 \times$ $(1 / 16), 32 \times(1 / 32), 64 \times(1 / 64), 128 \times$ (1/128), $256 \times 1 / 256)$, dan $512 \times(1 / 512)$ dengan PBS. Pengenceran yang digunakan untuk uji hemaglutinasi mulai dari pengenceran $4 \times(1 / 4), 8 \times(1 / 8), 16 \times$ $(1 / 16), 32 \times(1 / 32), \quad 64 \times(1 / 64), 128 \times$ (1/128), 256× (1/256), dan 512× (1/512), selanjutnya ke dalam tiap sumur ditambahkan $50 \mu \mathrm{L}$ suspensi SDMD 5\% lalu diaduk rata (digoyang-goyang) selama 5 menit, kemudian diinkubasi pada suhu $37{ }^{\circ} \mathrm{C}$ selama 60 menit dan didiamkan semalam pada suhu kamar. Pengamatan dilakukan untuk melihat pengenceran tertinggi dari serum darah tikus yang dapat mengaglutinasi sel darah merah domba.

\section{HASIL DAN PEMBAHASAN}

Efek imunostimulan infus buah mahkota dewa (Phaleria macrocarpa (Scheff.) Boerl.) terhadap sekresi antibodi tikus putih jantan menggunakan metode hemaglutinasi. Uji hemaglutinasi dilakukan dengan hewan coba diinduksi terlebih dahulu dengan antigen SDMD $5 \%$ secara intraperitonial untuk mempercepat absorpsi atau penyerapan antigen. SDMD adalah antigen polivalen yang mempunyai lebih dari satu determinan (Alam, dkk. 2011). Menurut (Baratawidjaja, 2006) determinan antigen atau epitop merupakan bagian antigen yang dapat membuat kontak dengan reseptor antibodi, dan menginduksi pembentukan antibodi yang diikat dengan spesifik oleh reseptor antibodi.Antigen yang telah diinduksikan ke dalam tubuh hewan coba tikus akan dikenal oleh sistem imun spesifik dengan membentuk sel B memori. Antigen akan merangsang sel B untuk berubah menjadi sel plasma dan mensekresi antibodi spesifik (Hendarsula, 2011). Antibodi pertama yang terbentuk adalah Imunoglubulin $M$ (IgM). Pada hari keenam dan hari ketujuh dalam serum mulai dapat dideteksi antibodi IgG (Srihidayati, dkk., 2012).

Hasil uji efek imunostimulan infus buah mahkota dewa (Phaleria macrocarpa (Scheff.) Boerl.) konsentrasi $7,5 \%, 15 \%$, dan $30 \%$ terhadap sekresi 
Efek Imunostimulan Infus Buah Mahkota Dewa (Phaleria macrocarpa (Scheff.) Boerl.) Asal Kab. Sidrab Sulawesi Selatan terhadap Sekresi Antibodi Tikus Putih (Rattus Norvegicus) Jantan dengan Teknik Hemaglutinasi

antibodi dengan metode hemaglutinasi setelah ditransformasi dapat dilihat pada tabel 1 dan 2 .

Hasil pengamatan menunjukkan titer tertinggi pada kelompok kontrol SDMD yaitu $1 / 16$ yaitu 1,40 , sedangkan pada kelompok kontrol normal tidak terjadi aglutinasi. Titer tertinggi pada kelompok perlakuan adalah 1/32 dengan titer 2,01 yaitu pada konsentrasi 7,5\%, $15 \%$, dan 30. Berdasarkan nilai rata-rata titer dapat disimpulkan terjadi peningkatan titer antibodi pada kelompok perlakuan dibandingkan dengan kelompok kontrol dengan kata lain infus buah mahkota dewa memberikan efek imunostimulan dengan titer tertinggi secara berturut-turut pada konsentrasi $7,5 \%$, konsentrasi $15 \%$ dan konsentrasi $30 \%$. Semakin tinggi dosis yang diberikan semakin rendah titer antibodi yang diperlihatkan. Uji hemaglutinasi dilakukan pada hari ketujuh karena pada hari tersebut diharapkan telah terdapat antibodi khususnya Imunoglobulin G dalam serum, berdasarkan pustakan antibodi terbentuk 5-10 hari setelah terpapar antigen (baratawidjaya,2009).

Tabel 1. Titer aglutinasi pada tikus putih (Rattus norvegicus) jantan yang diinduksi sel darah merah domba

\begin{tabular}{cccccc}
\hline \multirow{2}{*}{ Replikasi } & \multicolumn{5}{c}{ Titer Aglutinasi } \\
\cline { 2 - 6 } & Kontrol normal & Kontrol SDMD & Infus 7,5\% & Infus 15\% & Infus 30\% \\
\hline I & - & $1 / 4^{*}$ & $1 / 32^{*}$ & $1 / 16^{*}$ & $1 / 16^{*}$ \\
II & - & $1 / 16^{*}$ & $1 / 32^{*}$ & $1 / 32^{*}$ & $1 / 4^{*}$ \\
III & - & $1 / 8^{*}$ & $1 / 16^{*}$ & $1 / 16^{*}$ & $1 / 16^{*}$ \\
\hline
\end{tabular}

Tabel 2. Data titer aglutinasi pada uji hemaglutinasi setelah ditransformasi dengan [2 log (titer) +1$]$

\begin{tabular}{cccccc}
\hline \multirow{2}{*}{ Replikasi } & \multicolumn{5}{c}{ Titer Aglutinasi } \\
\cline { 2 - 6 } & Kontrol normal & Kontrol SDMD & Infus 7,5\% & Infus 15\% & Infus 30\% \\
\hline I & - & $0,20^{*}$ & $2,01^{*}$ & $1,40^{*}$ & $1,40^{*}$ \\
II & - & $1,40^{*}$ & $2,01^{*}$ & $2,01^{*}$ & $0,20^{*}$ \\
III & - & $0,80^{*}$ & $1,40^{*}$ & $1,40^{*}$ & $1,40^{*}$ \\
Jumlah & - & $2,40^{*}$ & $5,42^{*}$ & $4,81^{*}$ & $3,00^{*}$ \\
Rata-rata & - & $0,80^{*}$ & $1,81^{*}$ & $1,60^{*}$ & $1,00^{*}$ \\
\hline
\end{tabular}

Berdasarkan analisis data one way analysis of variance (ANOVA) memperlihatkan bahwa pemberian infus buah mahkota dewa (Phaleria macrocarpa (Scheff.) Boerl.) menunjukkan nilai signifikansidengan $\mathrm{P}<0,05$ yang menunjukkan ada perbedaan antara perlakuan yang diujikan.

Analisis dilanjutkan dengan uji LSD (Least Significant Different). Hasil yang diperoleh kelompok kontrol normal dan kontrol SDMD menunjukkan perbedaan yang nyata (signifikan). Kelompok infus $7,5 \%$ dan infus $15 \%$ menunjukkan tidak ada perbedaan tetapi menunjukkan perbedaan yang nyata (signifikan) dengan kelompok kontrol normal dan kontrol SDMD. Dapat disimpulkan bahwa infus buah mahkota dewa konsentrasi 7,5\% dengan titer 1,8.

\section{KESIMPULAN}

Berdasarkan hasil penelitian dan analisis data, maka disimpulkan bahwa: Infus buah mahkota dewa memiliki efek imunostimulan, dengan titer antibodi tertinggi yaitu pada konsentrasi $7,5 \%$ 
DAFTAR PUSTAKA

1. Alam,G dkk. 2011. Uji Efek Jus Buah Mengkudu (Morinda citrifolia Linn.) terhadap Aktivitas Imunoglobulin M (IgM) Dan Imunoglobulin $G$ (IgG) Pada Mencit (Mus musculus). Makassar: Universitas Hasanuddin.

2. Aurelia. 2006. Pengaruh Pemberian Rebusan Buah Mahkota Dewa (Phaleria Macrocarpa) Terhadap Aktivitas Fagositosis Makrofag Pada Mencit Balb/C Yang Diinfeksi Salmonella Typhimurium. Fakultas Kedokteran. Semarang: Universitas Diponegoro.

3. Baratawidjaja, K.G., dan Rengganis, I. 2009. Imunologi Dasar. Ed. VIII. Jakarta: Balai Penerbit FKUI.

4. Baratawidjaja, K.G. 2006. Imunologi Dasar. Edisi VII. Jakarta: Penerbit Fakultas Kesehatan Universitas Indonesia.

5. Gunawan. 2007. Farmakologi Terapi $V$. Departemen Farmakologi dan Terapeutik Fakultas Kedokteran: Universitas Indonesia

6. Hendarsula, A.R. 2011. Uji Aktivitas Imunostimulan Ekstrak Etanol Sarang Semut pada Tikus Putih Jantan. Depok: Fakultas Matematika dan Ilmu Pengetahuan Alam.
7. Maratani. 2006. Pengaruh Pemberian Rebusan Buah Mahkota Dewa (Phaleria macrocarpa) Terhadap Produksi Reactive Oxygen Intermediate (ROI) Makrofag Pada Mencit Balb/C Yang Diinfeksi Salmonella Typhimurium. Semarang: Fakultas Kedokteran Universitas Diponegoro.

8. Mulyaningsih, S. 2007. Aktivitas Imunostimulan Ekstrak Etanol Daun Rambutan (Nephelium lappaceum L.) pada mencit. Yogyakarta: Universitas Islam Indonesia.

9. Nugroho. 2012. Efek Pemberian Kombinasi Buah Sirih (Piperbetle L) Fruit, Daun Miyana (Plectranthusscutellariodes (L) R.BR) LEAF, Madu dan Kuning Telur Terhadap Peningkatan Aktivitas dan Kapasitas Fagositosis Sel Makrofag. Jakarta: Badan Litbangkes.

10. Srihidayati, M dkk. 2012. Efek Imunostiimulan Dari Kultur Kering Lactobacillus Casei Pada Hewan Uji Kelinci (Oryctolagus cuniculus) Jantan. Makassar: Universitas Hasanuddin.

11. Wibowo,S. 2013. Herbal ajaib. Perpustakaan Nasional PT. Pustaka Makmur. 